\title{
Determination and Evaluation of the Parameters for the Green \& AMPT Infiltration Equation in Some Agricultural Soils in Mexico
}

\author{
Jorge Víctor Prado Hernández 1,2,*, Fermín Pascual Ramírez ${ }^{3}$, David Cristóbal Acevedo ${ }^{2,4}$, \\ Mauricio Carrillo García ${ }^{2,5}$ and Antonio Martínez Ruíz 2,6 \\ ${ }^{1}$ Department of Soils, Graduate School Professor of Agricultural Engineering and Integral Water \\ Use, 56230 Chapingo, Estado de México, México; ac12493@chapingo.mx, vpradohdez@gmail.com \\ ${ }^{2}$ Universidad Autónoma Chapingo, Carretera México-Texcoco, km 38.5, Chapingo, Estado de \\ México. C.P. 56230, México \\ ${ }^{3}$ Integral Management of Water Resources, Institute of Research in Ecosystems and Sustainability, \\ UNAM Campus Morelia, Michoacán, México; fpascualr@iies.unam.mx \\ ${ }^{4}$ Departament of Soils, Soils Physics Laboratory Chief, cristobalacevdo@yahoo.com.mx \\ ${ }^{5}$ Departament of Irrigation, Graduate School Professor Agricultural Engineering and Integral Water \\ Use, 56230 Chapingo, Estado de México, México; mauricio@correo.chapingo.mx \\ ${ }^{6}$ Agricultural Engineering and Integral Water Use, 56230 Chapingo, Estado de México, México; \\ mara2883@hotmail.com \\ *Author for correspondence.
}

\begin{abstract}
An adequate representation of the water infiltration process in the soil allows improving the efficiency in application and the uniformity in surface irrigation. The Green and Ampt model has shown a good representation of the process, and researchers from the United States Department of Agriculture (USDA) determined the values of their parameters for soils of that country, which are shown in tables or through functional relationships and this information is used as reference in several parts of the world, although there is no certainty that they are representative of the soils in Mexico. In this study, the parameters of the Green \& Ampt equation were determined and evaluated in some soils of agricultural importance in Mexico. The parameters were obtained in four ways: one of them applied a methodology adapted from Brooks and Corey to quantify the wetting front capillary pressure head and used an permeameter under constant hydraulic head to determine the saturated hydraulic conductivity, and the other three consisted in taking them from three studies reported by the USDA. The values of the parameters suggested in Mexico drastically underestimated the results with relative errors (RE) in a range of -49.0 to $-94.0 \%$ and the most representative were those obtained with the methodology proposed in this research with RE of 15.0 to $6.0 \%$.
\end{abstract}

Keywords: water in the soil; surface irrigation; water storage; irrigation modelling; soil hydrodynamics

\section{Introduction}

The surface irrigation method is the one most frequently used to apply water in the different districts and irrigation units in Mexico, used in $92 \%$ of the area under irrigation [1]. However, it is the one with lowest application efficiency, which means that a large part of the water volume applied is lost so it is essential to increase the efficiency of application of this irrigation method. For this purpose, it is necessary to have a detailed understanding of the infiltration process, since it 
allows us to calculate an optimal irrigation time and with that to increase the efficiency of application. However, the complex infiltration process can be described through mathematical equations, only approximately [2].

Throughout time, numerous mathematical expressions have been developed to represent the infiltration process in the soil, which, in general, can be classified into three groups: (1) with physical base, (2) semi-empirical, and (3) empirical [3]. The models with physical base have a relatively strong physical backing, but they are complex and difficult to use. The inconvenience with the empirical equations is that their parameters do not have a particular physical meaning, but rather they are determined through statistical regression methods and are evaluated based on experimental data. Therefore, it is convenient to have a model that is found in an intermediate point $[4,5]$.

A simple theoretical approach, although useful, was suggested for the infiltration process in 1911 by Green and Ampt in their classic article about the flow of air and water through soils [6]. The Green \& Ampt infiltration model represents in an acceptable way the water movement in stratified soils [7, 8], the water movement in sub-superficial agricultural drains [9], the surge flow irrigation [10], the wetting patterns for surface emitters in trickle irrigation [11, 12], to study the infiltration in sprinkler irrigation [13], and to estimate the superficial runoff in watersheds with different land uses and topographic conditions $[14,15,16]$.

The main hypotheses of the Green \& Ampt model are: (1) the Darcy law regulates the vertical flow of water, (2) the piston flow creates a different source of moisture in the soil profile that initially is uniformly dry, (3) the wetting front is characterized by a constant matric suction, independent of the time and the position, and (4) behind the wetting front, the soil is uniformly moisturized and the hydraulic conductivity is constant [17, 18]. The combination of these hypotheses leads to the Green \& Ampt infiltration equation which is written as [19, 20, 21]:

$$
I(t)=K_{s} t+\gamma \ln \left(1+\frac{I}{\gamma}\right) \text { with } \gamma=\left(h+\psi_{f}\right)\left(\theta_{s}-\theta_{i}\right),
$$

where $I(t)$ is the infiltration amount (cumulative infiltrated depth) $(\mathrm{cm})$ in time $\mathrm{t}(\mathrm{h}) ; \psi_{f}$ is the wetting front capillary pressure head $(\mathrm{cm}) ; \mathrm{h}$ is the water depth on the surface $(\mathrm{cm}) ; \theta_{s}$ is the soil water content at saturation $\left(\mathrm{cm}^{3} \cdot \mathrm{cm}^{-3}\right) ; \theta_{i}$ is the initial soil water content $\left(\mathrm{cm}^{3} \cdot \mathrm{cm}^{-3}\right)$; and $K_{s}$ is the hydraulic conductivity at saturation $\left(\mathrm{cm} \cdot \mathrm{h}^{-1}\right)$.

The wetting front capillary pressure can be obtained from the integration of the Brooks and Corey equation of the relative hydraulic conductivity [22], through the expression [23, 24]

$$
\boldsymbol{\psi}_{f}=\frac{2+3 \lambda}{1+3 \lambda}\left(\frac{\psi_{b}}{2}\right)
$$

where $\psi_{b}$ is the bubbling pressure and $\lambda$ is the pore-size distribution index.

Equation (2) was modified by the authors of reference [25] and was the equation used in our research, and is expressed as

$$
\boldsymbol{\psi}_{f}=\frac{2 \lambda+3}{2 \lambda+2}\left(\frac{\psi_{b}}{2}\right)
$$

From the laboratory experimentation with many types of soils, Brooks and Corey [22, 26] concluded that $\psi_{f}$ can be expressed as a logarithmic function of effective saturation $\left(S_{e}\right)$

$$
S_{e}=\left[\frac{\psi_{b}}{\psi}\right]^{\lambda} \text { for } \psi \geq \psi_{e}
$$


where $S_{e}$ is the effective saturation, $\psi_{b}$ is the bubbling pressure, $\psi$ is the capillary pressure that corresponds to moisture $\theta$ and $\psi_{e}$ is the air entry pressure.

The effective saturation is the relationship between available moisture and the maximum moisture content possible, expressed as

$$
S_{e}=\frac{\theta-\theta_{r}}{\eta-\theta_{r}}
$$

where $\theta$ is the soil water content; $\theta_{r}$ is the residual soil water content and $\eta$ is the total soil porosity.

According to reference [26], $\theta_{r}, \psi_{b} \mathrm{y} \psi_{e}$ are curve fitting parameters determined from a plot of the capillary pressure as a function of $S_{e}$ on a log-log plot (Figure 1). The parameter $\theta_{r}$ is defined as that saturation value which provides the best fit to straight line, for saturations greater than a critical capillary pressure called the $\psi_{e}$. The exponent $\lambda$ is the negative of the slope straight line. The intercept at the ordinate where $\ln \left(S_{e}\right)=0$ defines $\ln \left(\psi_{b}\right)$, and the point where the measured curve intersects the straight line determines $\ln \left(\psi_{e}\right)$. Some researchers assume that the bubbling pressure $\psi_{b}$ and the air entry pressure $\psi_{e}$ are similars [23, 27].

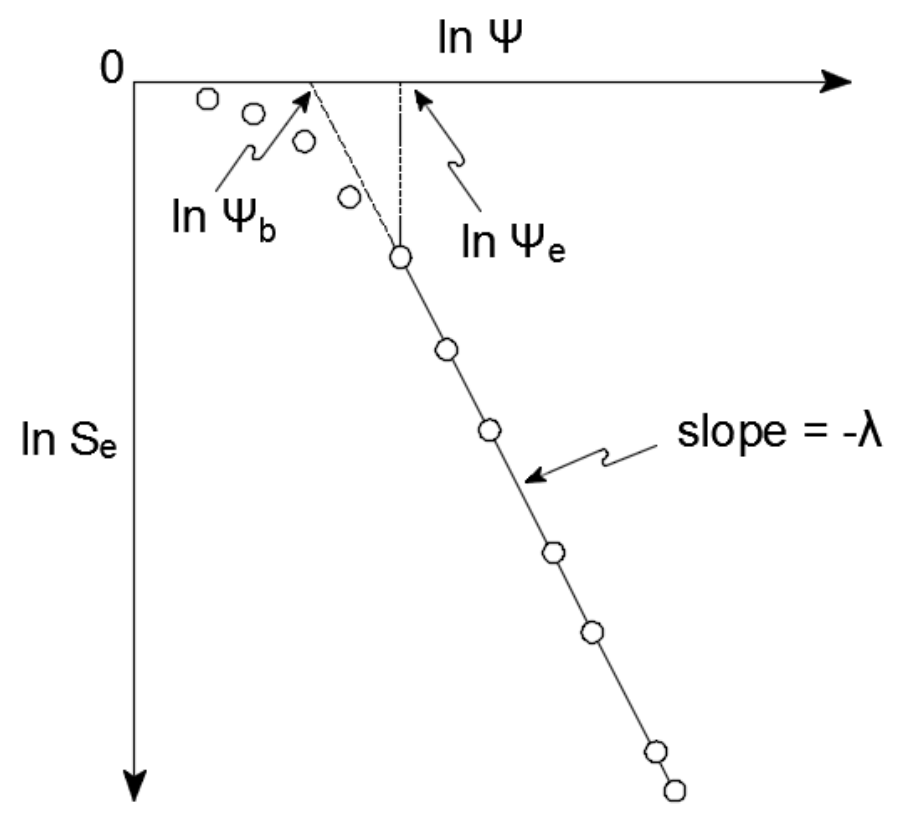

Figure 1. Parameters of effective saturation (Adapted from references [22, 26], Figure 2, p. 5 and 14 , respectively).

For the design of surface irrigation in Mexico, references [19] and [20] suggest using the parameters of the Green \& Ampt function obtained by researchers of the United States Department of Agriculture and reported by references [28] and [29] in 1981 and 1982, respectively. A more complete and recent database that integrates and complements the prior studies, generated from the study of approximately 5000 soil horizons in this country, and reported in 1983, is offered by reference [25]; however, the standard deviation of their values for a same textural class is very broad. To overcome this problem, the wetting front capillary pressure for a soil of well-identified texture can be obtained through the bubbling pressure in function of the soil water content at saturation [30] and the contents of sand, clay and organic matter [27].

The application of the Green \& Ampt equation in Mexico with the values of the parameters reported by the USDA researchers, as suggested by some researchers and government institutions $[19,20]$, does not guarantee a good representation of water infiltration due to the heterogeneity of the soils in the country. Therefore, the objective of this research was to obtain the parameters of the 
Green \& Ampt equation with information from the USDA, and a laboratory procedure, in some soils of agricultural importance in Mexico, and to evaluate their accuracy through the comparison of the accumulated infiltration depths estimated with field measures to determine the most appropriate for soils in Mexico.

The parameters $K_{s}, \theta_{s}$, and $\psi_{f}$ of the Green-Ampt equation (1) were obtained from ten soil samples from six states of the Mexican Republic, primarily from sites with important agricultural production. The parameter $\psi_{f}$ was obtained with equation (3), where parameters $\lambda$ and $\psi_{b}$ were calculated from the water retention curve and by solving simultaneously equations (4) and (5). Later, these parameters were compared to the values reported in tables and those generated with the equations proposed by three researchers from the USDA in references [25], [30] and [27], published in 1983, 1986 and 2006, respectively. Finally, the progress of the accumulated infiltrated depths estimated with the Green \& Ampt model and the parameters from the methodologies described with regards to the measurements with a double-ring infiltrometer in four of the sites sampled, were compared.

The use of the parameters reported in reference [25] and suggested for their use in Mexico did not turn out to be convenient. The values of the wetting front capillary pressure $\psi_{f}$ obtained from the water retention curve with the methodology proposed in this study and the values of the hydraulic conductivity at saturation obtained in the laboratory were the most representative.

\section{Materials and methods}

\subsection{Soils studied}

The determination of the parameters was carried out in ten soil samples from soils with agricultural use, seven of them under irrigation and three rainfed. Sampling was performed in the states of Michoacán, Oaxaca, Sinaloa, Estado de México, Sonora and Baja California.

Five samples were taken in the state of Michoacán: two samples (Samples 1 and 2) in an agricultural zone at coordinates $796890 \mathrm{~m} \mathrm{~W}, 2110321 \mathrm{~m} \mathrm{~N}$ and $797010 \mathrm{~m} \mathrm{W,} 2110268 \mathrm{~m} \mathrm{~N}$; and three samples (Samples 8, 9 and 10) in a rainfed agricultural zone within a small micro-basin (El Malacate) with primarily forestry land use and located between coordinates $228272 \mathrm{~m} \mathrm{W,} 2172618$ $\mathrm{m} \mathrm{N}$ and $228280 \mathrm{~m} \mathrm{~W}, 2172366 \mathrm{~m} \mathrm{~N}$. The sample from Oaxaca (Sample 3) was obtained at coordinates $80406 \mathrm{~m} \mathrm{~W}, 1902726 \mathrm{~m} \mathrm{~N}$. In the state of Sinaloa the sample was taken at a point of coordinates $758451 \mathrm{~m} \mathrm{~W}, 2827577 \mathrm{~m} \mathrm{~N}$ (Sample 4). One sample was extracted from the Experimental Agricultural Field of Universidad Autónoma Chapingo (UACh) at coordinates 512 $888 \mathrm{~m} \mathrm{~W}, 2155431 \mathrm{~m} \mathrm{~N}$ (Sample 5), located in Estado de México. The sample from the state of Baja California (Sample 6) was taken at coordinates $656310 \mathrm{~m} \mathrm{~W}, 3601414 \mathrm{~m} \mathrm{~N}$. The sample from the state of Sonora (Sample 7) was obtained in the ejido of San Miguel Allende.

\subsection{Determinations performed in the soils}

In each case, five portions of soil were taken from the terrain, at a depth of approximately 30 $\mathrm{cm}$ and were mixed to form a homogeneous compound sample. Later they were transported to the UACh, where they were prepared for the corresponding analysis. The preparation consisted in drying the samples, grinding them in a porcelain mortar and sifting with a sieve of mesh 10 (mesh with openings of two millimeters).

To find the parameters of the Green \& Ampt equation in each of the samples, the following were determined: texture, initial soil water content $\left(\theta_{i}\right)$, soil water content at saturation $\left(\theta_{s}\right)$, residual soil water content $\left(\theta_{r}\right)$, particle soil density $\left(\rho_{s}\right)$, bulk soil density $\left(\rho_{b}\right)$, saturated hydraulic conductivity $\left(K_{S}\right)$ and the water retention curve. 
The saturated hydraulic conductivity was determined in laboratory with a permeameter under constant hydraulic head and applying the Darcy law, using $200 \mathrm{~g}$ of soil from each sample; we use this method because it is used as a reference to evaluate the accuracy of other methods [31] and because the determination of the parameter in the field is difficult to obtain due to the entrance of atmospheric air into the soils [32]. The texture and real density were found applying the AS-09 and AS-04 methods, respectively, from the Norma Oficial Mexicana NOM-021-SEMARNAT-2000 [33]. The apparent density was determined with the test tube method, using 50 grams of dry and sieved soil.

The water retention curve was obtained by following the procedure indicated in the AS-06 method of the Norma Oficial Mexicana NOM-021-SEMARNAT-2000. The volumetric moisture content was determined at tensions of $0.01,0.05,0.1,0.2,0.33,0.5,1.0,3.0,5.0,7.0,9.0,11.0,12.0$, 13.0, 15, 16.0 and 17.0 atmospheres, using the pressure cooker for low tensions and pressure membrane for high tensions.

To calculate effective saturation with the equation (5), a residual soil water content obtained at 17 atm of tension was considered, and a total porosity obtained with the equation

$$
\eta=\left(1-\frac{\rho_{\mathrm{b}}}{\rho_{\mathrm{s}}}\right) \times 100
$$

For the application of equation 1 a soil water content at saturation referred to a soil tension 0 atm was used.

\subsection{Green $\mathcal{E}$ Ampt models analyzed}

The difference between the models that are described next consisted in the way of obtaining parameters $K_{s}$ and $\psi_{f}$ of the equation (1), since in every case the $\theta_{s}$ was used which resulted from the laboratory determinations, and the $\theta_{i}$ is a variable that takes on the value of the moisture content prior to the infiltration.

\subsubsection{Model from the water retention curve}

This model was called Retention curve, where the $K_{S}$ was taken up again from the data obtained in the laboratory with the permeameter under constant hydraulic head method and the parameter $\psi_{f}$ was obtained by solving equations (3), (4) and (5) with information from the water retention curve.

The pressure in the wetting front capillary pressure was obtained from the water retention curve of the soil in a similar way as done by Brooks and Corey [22] and Brakensiek [23]; the difference in the method applied in our study is that we used a retention curve in a range of 0.01 to $17 \mathrm{~atm}$ as pointed out in previous paragraphs, and that parameters $\psi_{b}$ and $\lambda$ were obtained by solving simultaneously equations (4) and (5) by the method of minimum squares instead of a graphic method.

The reason to use a water retention curve in such a broad range of tensions instead of using a retention curve in a much smaller range, from 0 to $0.5 \mathrm{~atm}$ as they did in references [22] and [23], was because of the limitations of Mexican laboratories that do not allow obtaining soil moisture at such low tensions and do not allow distinguishing the moisture differentials with small tension differentials.

2.3.2 Model based on data reported by Rawls et al. (1983) 
This model was called Rawls et al. (1983) because the values of parameters $K_{s}$ and $\psi_{f}$ were taken from the study carried out by Rawls, Brakensiek \& Miller in 1983 [25].

2.3.3 Model based on the equation reported by Saxton et al. (1986)

This model was called Saxton et al. (1986) because the equation found by Saxton, Rawls, Romberger \& Papendick in 1986 [30] to calculate parameter $\psi_{b}$ in function of the soil water content at saturation $\theta_{S}\left(\mathrm{~cm}^{3} \mathrm{~cm}^{-3}\right)$, was used, whose expression is

$$
\psi_{b}=100\left[-0.108+0.34\left(\theta_{s}\right)\right]
$$

With the $\psi_{b}$ found, equations (3) and (4) were solved by the minimum squares method to obtain the value of $\lambda$, using the information from the retention curve, and then equation (5) was applied to obtain the value of parameter $\psi_{f}$. The value of $K_{s}$ obtained from the laboratory determination was used.

2.3.4 Model based on the equations obtained by Saxton-Rawls (2006)

This model was called Saxton-Rawls (2006) because the equations found by Saxton \& Rawls in 2006 [27] to calculate the parameter $\psi_{b}$ and one of the two values of $K_{s}$ contemplated, were used, in function of the content of clay, sand and organic matter, described as

$$
\begin{gathered}
\psi_{b}=\psi_{\mathrm{et}}+\left(0.02 \psi_{\mathrm{et}}-0.113 \psi_{\mathrm{et}}-0.70\right), \\
K_{S}=1930\left(\theta_{S}-\theta_{33}\right)^{(3-\beta)}, \\
\psi_{\mathrm{et}}=-21.67 \mathbf{S}-27.93 \mathbf{C}-81.97 \theta_{(\mathrm{S}-33),} \\
\Theta_{(\mathrm{S}-33)}=\theta_{(\mathrm{S}-33) t}+\left(0.636 \theta_{(\mathrm{S}-33) t}-0.107\right), \\
\Theta_{(\mathrm{S}-33) t}=0.278 \mathbf{S}+0.034 \mathbf{C}+0.022 \mathbf{O M}-0.018(\mathbf{S} \times \mathbf{O M}) \\
-0.027(\mathrm{C} \times \mathbf{O M})-0.584(\mathbf{S} \times \mathbf{C})+0.078, \\
B=\frac{1}{B^{\prime}} \\
\theta_{S}=\theta_{33}+\theta_{(S-33)}-0.097 \boldsymbol{S}+0.043, \\
\theta_{33}=\theta_{33 t}+\left[1.28\left(\theta_{33 t}\right)^{2}-0.374\left(\theta_{33 t}\right)-0.015\right], \\
\theta_{33 t}=-0.251 \boldsymbol{S}+0.195 \boldsymbol{C}+0.011 \boldsymbol{O M}+0.006(\boldsymbol{S} \times \boldsymbol{O M}) \\
-0.027(\boldsymbol{C} \times \boldsymbol{O M})+0.452(\boldsymbol{S} \times \boldsymbol{C})+0.299, \\
\theta_{1500}=\theta_{1500 t}+\left(0.14 * \theta_{1500 t}-0.02\right), \\
\theta_{1500 t}=-0.024 \boldsymbol{S}+0.487 \boldsymbol{C}+0.006 \boldsymbol{O M}+0.005(\boldsymbol{S} \times \boldsymbol{O M}) \\
-0.013(\boldsymbol{C} \times \boldsymbol{O M})+0.068(\boldsymbol{S} \times \boldsymbol{C})+0.031,
\end{gathered}
$$

where $\psi_{e t}$ is a first approximation to the value of $\psi_{b}(\mathrm{KPa}) ; \mathrm{S}, \mathrm{C}, \mathrm{OM}$ are the fractions of the weights of clay, sand and organic matter, respectively $(\%) ; \theta_{(S-33)}$ is the moisture differential between the 
content of soil water content at saturation and at $33 \mathrm{KPa}\left(\mathrm{cm}^{3} \mathrm{~cm}^{-3}\right) ; \theta_{(S-33) t}$ is the first solution of $\theta_{(S-33)} ; K_{S}$ is the saturated hydraulic conductivity $\left(\mathrm{mm} \mathrm{h}^{-1}\right) ; \theta_{S}$ is the soil water content at saturation $\left(\mathrm{cm}^{3} \mathrm{~cm}^{-3}\right) ; \theta_{33}$ is the water content that corresponds to a tension of $33 \mathrm{KPa}\left(\mathrm{cm}^{3} \mathrm{~cm}^{-3}\right) ; \theta_{33 t}$ is a first approximation to the value of $\theta_{33} ; \theta_{1500}$ is the water content that corresponds to a tension of 1500 $\mathrm{KPa}\left(\mathrm{cm}^{3} \mathrm{~cm}^{-3}\right)$; and $\theta_{1500 t}$ is a first approximation to the value of $\theta_{1500}$.

The calculation shape of parameter $\lambda$ was similar to the one performed in the method denominated Saxton et al. (1986). The other value of $K_{S}$ employed was taken from the laboratory result.

\subsection{Evaluation of the Green $\mathcal{E}$ Ampt models}

The representativeness of the models considered was carried out by comparing their results to the ones obtained from an infiltration test performed through the double-ring infiltrometer method. The comparison was made in the soil of the UACh (Sample 5) and in the three soils of the microbasin of the state of Michoacán (Samples 8, 9 and 10).

Pior to the beginning of the infiltration test, a small soil sample was taken with a drill to determine the initial moisture content in the four sites analyzed.

The evaluation of the degree of accuracy in the estimation of the infiltrated depth from the models analyzed was carried out with the standard error (SE), average error (AE) and relative error (RE), applying the following expressions [34]:

$$
\begin{aligned}
& S E=\sqrt{\frac{\sum_{i=1}^{n}\left(P_{i}-O_{i}\right)^{2}}{n-1}}, \\
& A E=\frac{\sum_{i=1}^{n}\left(P_{i}-O_{i}\right)}{n} \\
& R E=\left(\frac{\sum_{i=1}^{n} P_{i}-\sum_{i=1}^{n} o_{i}}{\sum_{i=1}^{n} O_{i}}\right) \times 100,
\end{aligned}
$$

where $O_{i}$ are the values observed, $P_{i}$ are the values predicted and $\mathrm{n}$ is the number of data evaluated.

It is said that the model has good accuracy to predict the values observed as the values of the statistical parameters SE, AE and RE approach zero.

\section{Results and discussion}

The soils analyzed corresponded to six of the twelve textural classes that the USDA

\begin{tabular}{|c|c|c|c|c|c|c|c|c|c|}
\hline Sample & $\begin{array}{c}\text { State of } \\
\text { origin }\end{array}$ & $\begin{array}{c}\text { Sand } \\
(\%)\end{array}$ & $\begin{array}{l}\text { Clay } \\
(\%)\end{array}$ & $\begin{array}{l}\text { Silt } \\
(\%)\end{array}$ & Texture & $\begin{array}{c}\eta \\
\left(\mathrm{cm}^{3} \mathrm{~cm}^{-3}\right)\end{array}$ & $\begin{array}{c}\begin{array}{c}\theta \mathrm{e}^{\mathrm{a}} \\
\left(\mathrm{cm}^{3} \mathrm{~cm}^{-3}\right)\end{array} \\
\end{array}$ & $\begin{array}{c}\theta_{\mathrm{s}} \\
\left(\mathrm{cm}^{3} \mathrm{~cm}^{-3}\right)\end{array}$ & $\begin{array}{l}\text { OM } \\
(\%)\end{array}$ \\
\hline 1 & Michoacán & 8.9 & 71.8 & 19.3 & Clay & 0.50 & 0.04 & 1.35 & --- \\
\hline 2 & Michoacán & 8.9 & 73.8 & 17.3 & Clay & 0.59 & 0.11 & 1.40 & --- \\
\hline 3 & Oaxaca & 54.9 & 21.8 & 23.3 & Sandy clay loam & 0.57 & 0.45 & 0.66 & --- \\
\hline 4 & Sinaloa & 36.9 & 37.8 & 25.3 & Clay loam & 0.50 & 0.40 & 0.75 & --- \\
\hline 5 & México & 48.9 & 25.8 & 25.3 & Sandy clay loam & 0.55 & 0.44 & 0.72 & 1.75 \\
\hline 6 & $\begin{array}{c}\text { Baja } \\
\text { California }\end{array}$ & 40.3 & 23.4 & 36.3 & Loam & 0.52 & 0.41 & 0.80 & 0.75 \\
\hline 7 & Sonora & 18.3 & 37.72 & 44.0 & Silty clay loam & 0.54 & 0.42 & 0.83 & 1.61 \\
\hline 8 & Michoacán & 32.0 & 32.5 & 35.5 & Clay loam & 0.48 & 0.274 & 0.48 & 4.80 \\
\hline
\end{tabular}
contemplates, covering from loam to clay (Table 1).

Table 1. Characteristics of the soils analyzed. 


\begin{tabular}{|c|c|c|c|c|c|c|c|c|c|}
\hline & & & & & & & & & of 17 \\
\hline 9 & Michoacán & 28.0 & 25.0 & 47.0 & Loam & 0.57 & 0.246 & 0.57 & 7.30 \\
\hline 10 & Michoacán & 34.0 & 15.6 & 50.4 & Silty loam & 0.81 & 0.477 & 0.81 & 8.40 \\
\hline
\end{tabular}

Table 1 shows that the total porosity $(\eta)$ of Sample 8, from Michoacán and of Clay loam texture, is quite similar to the mean reported by a soil in the USA with the same texture (Table 2); in contrast, the rest of the soils studied (Samples 1, 2, 3, 4, 5, 6, 7, 9 and 10) presented values of total porosity higher than the mean values that correspond to soils equivalent in texture. In general, the total porosity values found are more similar to the higher limits of the intervals of total porosity in Table 2. However, although the total porosity of the samples analyzed is relatively high, the values are found within the interval described in the literature where it is mentioned that the porosity of a soil can reach up to $60 \%$ and even that percentage can increase in presence of organic matter [35, 36].

The values obtained of effective porosity $\left(\theta_{e}\right)$ turned out to be similar to the mean values found for soils of the same texture in the USA in Samples 6, 7, 10. In Samples 1, 2, 8 and 9 they were lower (89.6, 71.4, 12.8 and 43.3\%, respectively) and in Samples 3, 4 and 5 they were higher $(36.4,29.4$ and $33.3 \%$, respectively). The differences in Samples 1 and 2 are notable, and the very small values of Table 1 are attributed to their high residual humidity.

Table 2. Values of total porosity $(\boldsymbol{\eta})$ and effective porosity $\left(\boldsymbol{\theta}_{\boldsymbol{e}}\right)$ of equivalent textures, extracted from Table 2 from reference [25].

\begin{tabular}{|c|c|c|}
\hline Soil texture & $\begin{array}{c}\eta \\
\left(\mathrm{cm}^{3} \mathrm{~cm}^{-3}\right)\end{array}$ & $\begin{array}{c}\theta_{e} \\
\left(\mathrm{~cm}^{3} \mathrm{~cm}^{-3}\right)\end{array}$ \\
\hline Loam & $\mathbf{0 . 4 6 3}(0.375-0.551)^{\mathrm{a}}$ & $\mathbf{0 . 4 3 4}(0.334-0.534)$ \\
\hline Silty loam & $0.501(0.420-0.582)$ & $\mathbf{0 . 4 8 6}(0.394-0.578)$ \\
\hline Sandy clay loam & $0.398(0.332-0.464)$ & $\mathbf{0 . 3 3 0}(0.235-0.425)$ \\
\hline Clay loam & $\mathbf{0 . 4 6 4}(0.409-0.519)$ & $0.309(0.279-0.501)$ \\
\hline Silty clay loam & $\mathbf{0 . 4 7 1}(0.418-0.524)$ & $\mathbf{0 . 4 3 2}(0.347-0.517)$ \\
\hline Clay & $\mathbf{0 . 4 7 5}(0.427-0.523)$ & $0.385(0.269-0.501)$ \\
\hline
\end{tabular}

${ }^{a}$ Number between parenthesis (), is the standard deviation \pm

In Samples 1 and 2 the soil water content at saturation turned out to be higher than $100 \%$. These high contents of moisture are attributed to the percentage of clay that is part of the samples (higher than $70 \%$ ) and the class that these clays belong to, due to the behavior shown during the determination of water retention curves and according to the place where the samples were extracted, are inferred to be montmorillonites.

According to the Edaphology of the Digital Map of Mexico [37], Samples 1 and 2 were obtained from a soil that belongs to the order of vertisols, which are characterized by having montmorillonite clays, of type 2:1. This class of clay has the capacity of expanding to many times its original volume when water is added. This behavior, analogous to that of a hydrogel, explains the high percentage of saturation moisture obtained in the samples previously mentioned.

Table 3 shows the values found for parameters $\psi_{f}$ and $K_{s}$ from the Green \& Ampt equation, obtained for the models of Retention curve and Rawls et al. (1983). The order in which the results are presented responds to the increasing fineness of the textures found in the soils studied, to ease their analysis. The results from these models are reported in the same table because it would be expected for those of the Retention curve to be the most precise and because the Rawls et al. (1983) model is the one suggested for Mexico. Notable differences are seen in the values of $\psi_{f}$ in all the soil textures analyzed. In nine out of the ten soils, the Retention curve model found values that were within the 
range that the Rawls et al. (1983) model reports, and in most of the cases they were higher than the mean values.

Table 3. Green-Ampt parameters obtained with the Retention curve and Rawls et al. (1983) models.

\begin{tabular}{|c|c|c|c|c|c|}
\hline \multirow[t]{2}{*}{ Sample } & \multirow[t]{2}{*}{ Texture } & \multicolumn{2}{|c|}{$\begin{array}{l}\text { Wetted front capillary pressure } \\
\text { head } \\
\left(\psi_{f}\right) \\
(\mathrm{cm})\end{array}$} & \multicolumn{2}{|c|}{$\begin{array}{l}\text { Saturated hydraulic } \\
\text { conductivity } \\
\left(\mathrm{K}_{\mathrm{s}}\right) \\
\left(\mathrm{cm} \mathrm{h}^{-1}\right) \\
\end{array}$} \\
\hline & & $\begin{array}{c}\text { Retention } \\
\text { curve }^{\mathbf{a}}\end{array}$ & Rawls et al. (1983) & $\begin{array}{c}\text { Retention } \\
\text { curve }\end{array}$ & $\begin{array}{c}\text { Rawls et al. } \\
\quad(1983)\end{array}$ \\
\hline 6 & Loam & 63.90 & $8.89(1.33-59.38)^{\mathrm{c}}$ & 0.78 & 0.68 \\
\hline 9 & Loam & 40.50 & $8.89(1.33-59.38)$ & 17.00 & 0.68 \\
\hline 10 & Silty loam & 69.10 & $16.68(2.92-95.39)$ & 19.00 & 1.30 \\
\hline 3 & Sandy clay loam & 9.81 & $21.85(4.42-108.0)$ & 2.48 & 0.30 \\
\hline 5 & Sandy clay loam & 10.60 & $21.85(4.42-108.0)$ & 1.20 & 0.30 \\
\hline 4 & Clay loam & 9.98 & $20.88(4.79-91.10)$ & 0.36 & 0.20 \\
\hline 8 & Clay loam & 53.00 & $20.88(4.79-91.10)$ & 6.72 & 0.20 \\
\hline 7 & Silty clay loam & 86.74 & $27.30(5.67-131.5)$ & 0.93 & 0.20 \\
\hline 1 & Clay & 91.67 & $31.63(6.39-156.5)$ & 0.10 & 0.20 \\
\hline 2 & Clay & 7.40 & $31.63(6.39-156.5)$ & 0.19 & 0.06 \\
\hline
\end{tabular}

aFrom the solution of equations (2), (3) and (4), using the water retention curve.

bTaken from Table 2 of reference [25].

cThe values correspond to the textural class. Number in parenthesis () is the standard deviation $\pm$.

Concerning the values of saturated hydraulic conductivity presented in Table 3 , in nine of the ten samples analyzed they were higher in the Retention curve model and the difference was noticeable in five of the soils analyzed. The discrepancy could be due to differences in the physical properties of the soils and because in our study the parameter was determined with the constant head permeameter method and making use of altered samples; in contrast, in the study carried out by the researchers from reference [25], the saturated hydraulic conductivity was obtained through a semi-empirical equation in function of some physical characteristics of the soil and which has adjustment errors, using the equation obtained by reference [38]

$$
K_{S}=a \frac{\theta_{e}^{2}}{\psi_{b}^{2}}\left[\frac{\lambda^{2}}{(\lambda+1)(\lambda+2)}\right]
$$

where the constant $a$ represents the effects of various fluid constants and of the acceleration of gravity, and is equal to $21 \mathrm{~cm}^{3} \mathrm{~s}^{-1}$ [25].

In Tables 4 and 5, the wetted front capillary pressure and the saturated hydraulic conductivity of the models Saxton et al. (1986) and Saxton-Rawls (2006), respectively, are shown. In Table 5 only the values for Samples 5, 6, 7, 8, 9 and 10 are presented, and they were not calculated for the rest of the samples because their organic matter content was not determined (Table 1), necessary piece of data to apply the Saxton \& Rawls (2006) equations.

Table 4. Values of $\psi_{f}$ used by the Saxton et al. (1986) model.

\begin{tabular}{ccccc}
\hline Sample & $\begin{array}{c}\boldsymbol{\psi}_{\boldsymbol{b}}{ }^{\mathbf{a}} \\
(\mathbf{c m})\end{array}$ & $\begin{array}{c}\boldsymbol{\lambda} \\
(\text { Dimensionless) }\end{array}$ & $\begin{array}{c}\boldsymbol{\psi}_{\boldsymbol{f}} \\
(\mathbf{c m})\end{array}$ & $\begin{array}{c}\boldsymbol{K}_{\boldsymbol{S}^{\mathbf{b}}} \\
\left(\mathbf{m m} \mathbf{h}^{-\mathbf{1}}\right)\end{array}$ \\
\hline 1 & 263.57 & 0.88 & 166.90 & 0.10 \\
2 & 244.52 & 0.75 & 157.20 & 0.19 \\
3 & 13.43 & 0.39 & 9.14 & 2.48 \\
4 & 74.96 & 0.47 & 50.20 & 0.36
\end{tabular}




\begin{tabular}{ccccc}
5 & & & 10 of 17 \\
6 & 45.33 & 0.64 & 29.57 & 1.20 \\
7 & 31.45 & 0.43 & 21.22 & 0.78 \\
8 & 51.90 & 0.55 & 34.30 & 0.93 \\
9 & 86.80 & 0.51 & 57.81 & 6.72 \\
10 & 125.80 & 0.63 & 82.20 & 17.00 \\
\hline
\end{tabular}

aCalculated with the equation found Saxton et al. (1986).

bValues obtained from the laboratory.

Table 5. Values of $\psi_{f}$ and $K_{S}$ used by the Saxton-Rawls (2006) model.

\begin{tabular}{cccccc}
\hline Sample & $\begin{array}{c}\boldsymbol{\psi}_{\boldsymbol{b}}{ }^{\mathbf{a}} \\
(\mathbf{c m})\end{array}$ & $\begin{array}{c}\boldsymbol{\lambda} \\
\text { (Dimensionless) }\end{array}$ & $\begin{array}{c}\boldsymbol{\psi}_{\boldsymbol{f}} \\
(\mathbf{c m})\end{array}$ & $\begin{array}{c}\boldsymbol{K}_{\boldsymbol{s}^{\mathbf{a}}} \\
\left(\mathbf{m m} \mathbf{h}^{-1}\right)\end{array}$ & $\begin{array}{c}\boldsymbol{K}_{\boldsymbol{s}^{\mathbf{b}}} \\
\left(\mathbf{m m} \mathbf{~ h}^{-\mathbf{1}}\right)\end{array}$ \\
\hline 5 & 43.53 & 0.63 & 28.44 & 0.61 & 1.20 \\
6 & 63.45 & 0.51 & 42.26 & 0.61 & 0.78 \\
7 & 101.82 & 0.65 & 66.32 & 0.17 & 0.93 \\
8 & 76.77 & 0.49 & 51.26 & 0.25 & 6.72 \\
9 & 95.88 & 0.59 & 63.03 & 0.45 & 17.00 \\
10 & 85.84 & 0.51 & 57.14 & 0.93 & 19.00 \\
\hline
\end{tabular}

${ }^{a}$ Calculated with the equations found by Saxton \& Rawls (2006).

bValues obtained from the laboratory.

The values of parameter $\psi_{f}$ turned out to be different in the four models (Tables 3, 4 and 5). The values of parameter $K_{S}$ obtained in the laboratory also turned out to be different, as well as those calculated with the Saxton \& Rawls (2006) equations, particularly in the soils of Samples 8, 9 and 10 (Table 5). This behavior can be attributed to the fact that these soils have high contents of organic matter because they are agricultural soils in a micro-basin with predominately forestry use, situation that is not contemplated by the equations mentioned because the average value of the analyzed soils of the United States was 0.6 and $2.8 \%$ for the horizons B-C and A, respectively [27].In Figure 2, the evolution of the depth infiltrated obtained with the double-ring infiltrometer (measurement) and with the four models considered in an agricultural soil of Sandy clay loam texture is presented, from the Experimental Agricultural Field of the UACh (Sample 5). In the figure, two Saxton-Rawls (2006) are shown; the one indicated by Saxton-Rawls 1 (2006) used the value of parameter $K_{S}$ calculated with the Saxton and Rawls (2006) equations (column 5 of Table 5), and the one labelled as Saxton-Rawls 2 (2006) used the value obtained in the laboratory (column 6 of Table 5).

In Figure 2 it can be appreciated that the Retention curve model underestimated the results but it was the one that best represented the infiltration amount, followed in decreasing order of accuracy by the Saxton-Rawls 2 (2006) model which also underestimated them, Saxton-Rawls 1 (2006) with overestimation, Saxton et al. (1986) with overestimation and Rawls et al. (1983) with an important underestimation. It is important to highlight that the results of the Saxton-Rawls 2 (2006) model turned out to be quite similar to those of the Retention curve, with the disadvantage that during long periods of time the infiltration amount is made slightly slower and is distanced more from the values measured. The Saxton-Rawls 1 (2006) model had greater error in the estimation of accumulated infiltrated depth than the Saxton-Rawls 2 (2006) model because the calculation of the hydraulic conductivity at saturation was performed with an equation as a function of the contents of soil water at saturation, at field capacity and permanent wilting point, which in turn were obtained with empirical equations found for United States soils [39].

The better approximation of the Saxton-Rawls (2006) models compared to those of Saxton et al. (1986) and Rawls et al. (1983) is explained because it contemplates the particular characteristics of a soil from its texture and its organic matter content, in addition to being sustained by a larger database. Instead, the use of average values of parameter $\psi_{f}$ from a textural class in the Rawls et al. 
(1983) model generates strong errors because the range of variation of its values is very broad (column 4 of Table 3).

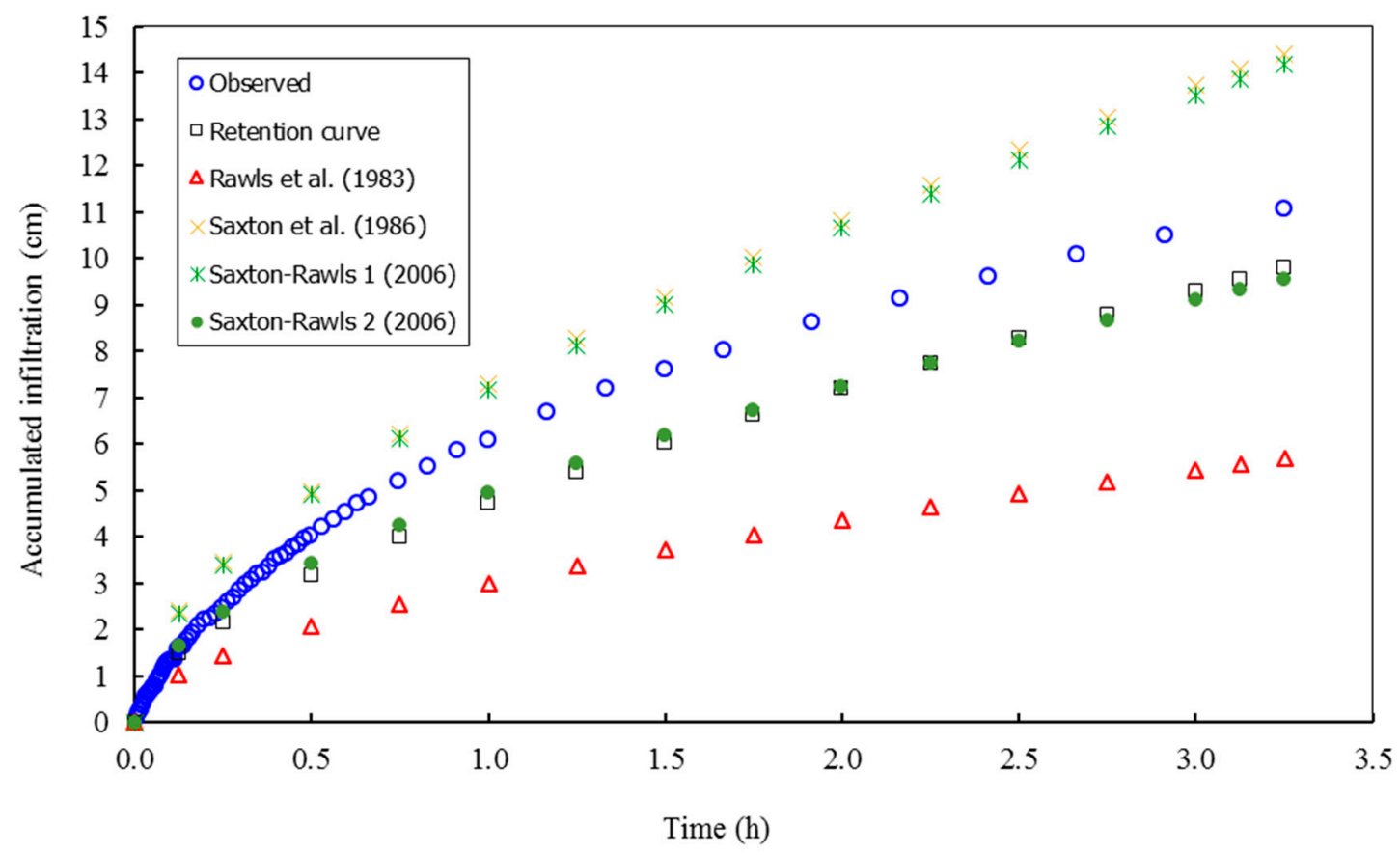

Figure 2. Accumulated infiltration depth in the soil from sample 5.

In Figures 3, 4 and 5, the progression of the infiltrated depth measured is shown, and that which resulted from the application of the Green-Ampt models considered. The Saxton-Rawls 1 (2006) and Saxton-Rawls 2 (2006) models correspond to the same description as those presented in Figure 2. The results correspond to the three soils considered from the el Malacate micro-basin in the state of Michoacán. In the three cases the models Retention curve and Saxton-Rawls 2 (2006) showed quite similar results and are the ones that best represent the values measured with a slight overestimation in long periods of time. In accuracy, the Rawls et al. (1986) model follows, with an overestimation that could be considered acceptable from the simplicity of the model and the scarce information required. The results from the Saxton-Rawls 2 (2006) and Rawls et al. (1983) models were very similar but with a notable underestimation and are considered inadequate. 


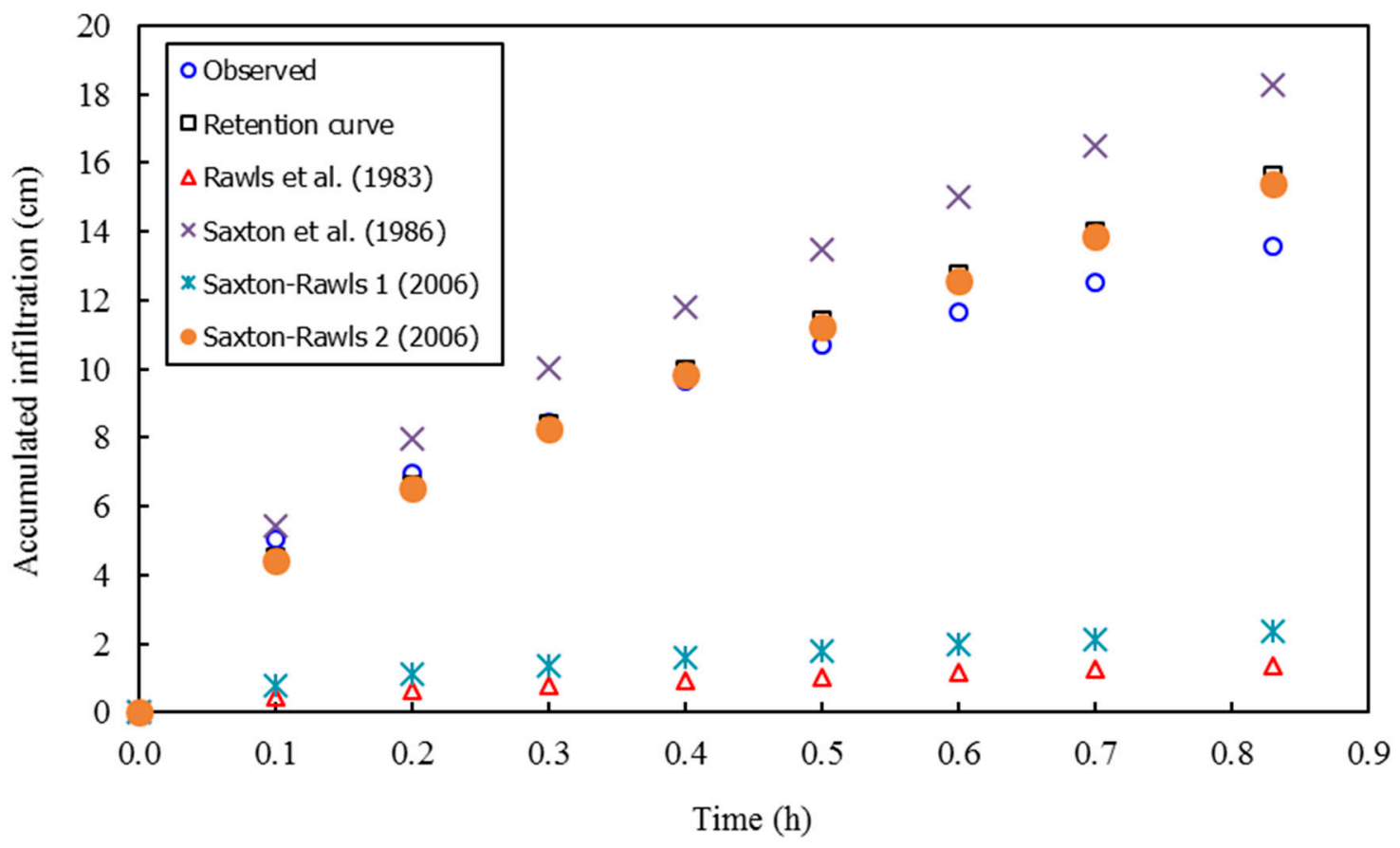

Figure 3. Accumulated infiltration depth in the soil of sample 8.

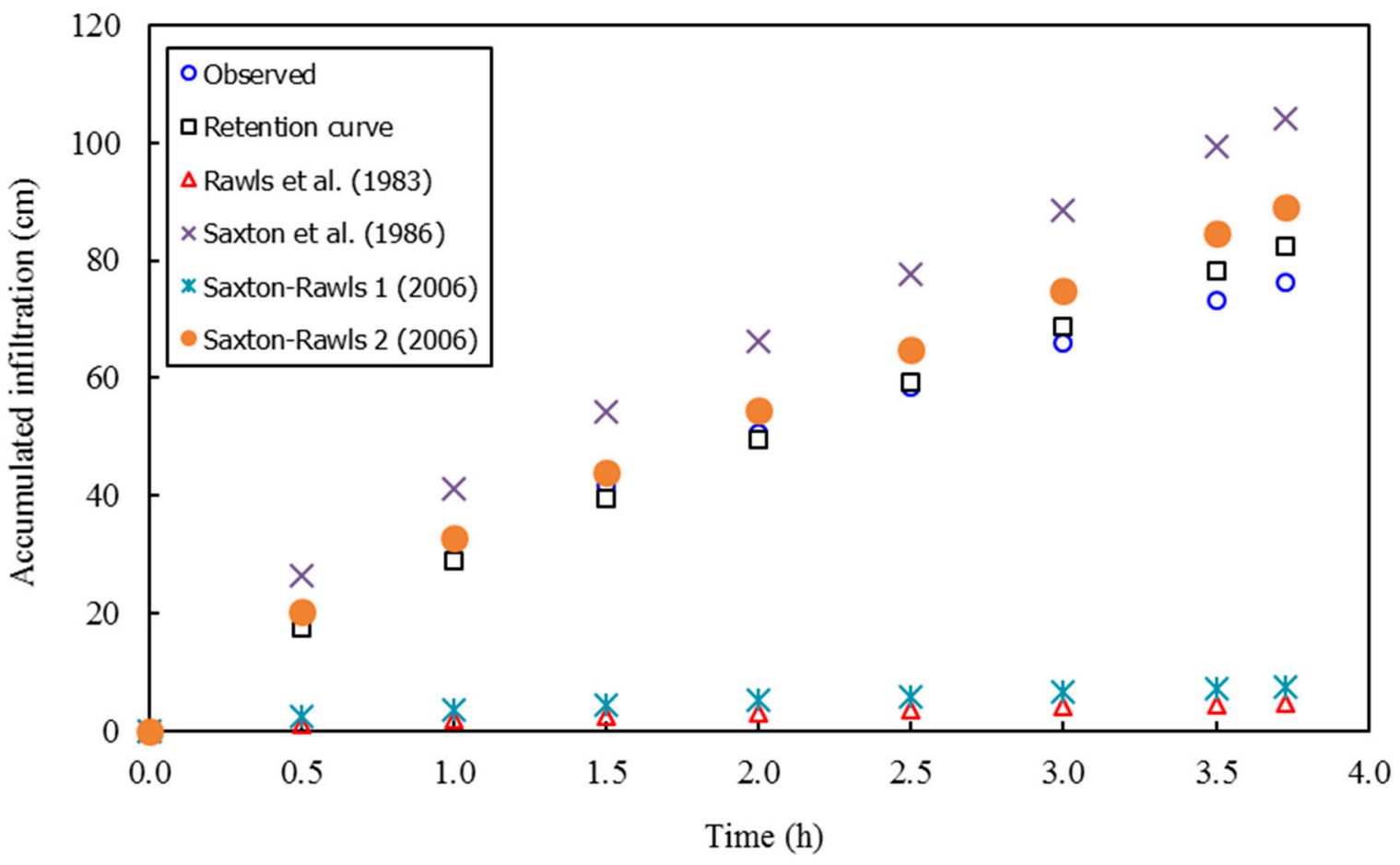

Figure 4. Accumulated infiltration depth in the soil of sample 9. 


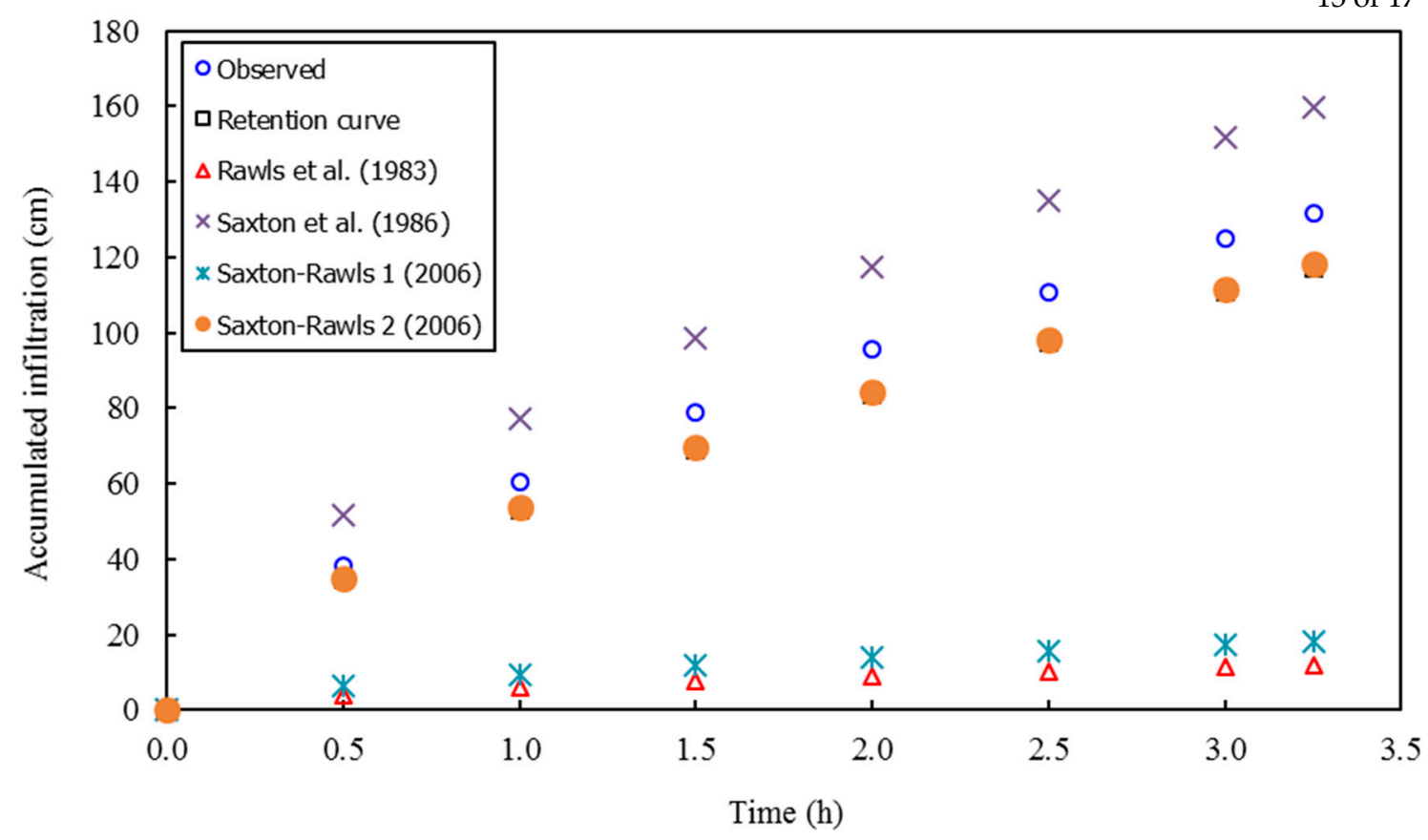

Figure 5. Accumulated infiltration depth in the soil of sample 10.

The statistical descriptors SE (cm), AE (cm) and RE (\%) allow specifying the power of estimation and quantifying the errors made with the application of each one of the Green \& Ampt models analyzed (Table 6). It is clear that the Rawls et al (1983) model suggested for Mexico is inadequate because in the four soils evaluated there were very high values of the three descriptors: from 3.97 to $82.14 \mathrm{~cm}$ in SE, from -3.37 to $-64.45 \mathrm{~cm}$ in $\mathrm{AE}$, and from -49.0 to $-91.0 \%$ in RE. The Saxton et al. (1986) model improved substantially the estimation of the infiltration amount because it included the parameter $\theta_{S}$ which is a property that is characteristic of a soil, sustained by the analysis of a much broader database. The Retention curve and Saxton-Rawls 2 (2006) models were the best and can be considered similar in their predictive quality, except in the soil from sample 9 where the Retention curve model overestimated the results to a lower degree.

Table 6. Statistical parameters of the estimated infiltrated depth.

\begin{tabular}{|c|c|c|c|c|c|c|c|c|c|c|c|c|}
\hline \multirow[b]{2}{*}{ Model } & \multicolumn{3}{|c|}{ Sample 5} & \multicolumn{3}{|c|}{ Sample 8} & \multicolumn{3}{|c|}{ Sample 9} & \multicolumn{3}{|c|}{ Sample 10} \\
\hline & $\begin{array}{c}\mathrm{SE} \\
(\mathrm{cm})\end{array}$ & $\begin{array}{l}\mathrm{AE} \\
(\mathrm{cm})\end{array}$ & $\begin{array}{l}\text { RE } \\
(\%)\end{array}$ & $\begin{array}{l}\mathrm{SE} \\
(\mathrm{cm})\end{array}$ & $\begin{array}{c}\mathrm{AE} \\
(\mathrm{cm})\end{array}$ & $\begin{array}{l}\text { RE } \\
(\%)\end{array}$ & $\begin{array}{l}\mathrm{SE} \\
(\mathrm{cm})\end{array}$ & $\begin{array}{l}\mathrm{AE} \\
(\mathrm{cm})\end{array}$ & $\begin{array}{l}\text { RE } \\
(\%)\end{array}$ & $\begin{array}{l}\mathrm{SE} \\
(\mathrm{cm})\end{array}$ & $\begin{array}{c}\mathrm{AE} \\
(\mathrm{cm})\end{array}$ & $\begin{array}{l}\mathrm{RE} \\
(\%)\end{array}$ \\
\hline Retention curve & 1.32 & -1.05 & -15.0 & 1.03 & 0.52 & 6.0 & 3.41 & 0.63 & 1.0 & 10.60 & -8.33 & -12.0 \\
\hline $\begin{array}{c}\text { Rawls et al. } \\
\text { (1983) }\end{array}$ & 3.97 & -3.37 & -49.0 & 9.19 & -7.89 & -90.0 & 52.07 & -43.60 & -94.0 & 82.14 & -64.45 & -91.0 \\
\hline $\begin{array}{l}\text { Saxton et al. } \\
\quad(1986)\end{array}$ & 2.24 & 1.94 & 28.0 & 2.85 & 2.21 & 25.0 & 18.89 & 15.45 & 33.0 & 20.76 & 16.84 & 24.0 \\
\hline $\begin{array}{c}\text { Saxton-Rawls } 1 \\
(2006)^{\mathrm{a}}\end{array}$ & 1.32 & 1.79 & 26.0 & 8.48 & -7.28 & -83.0 & 49.90 & -41.71 & -90.0 & 77.72 & -60.87 & -86.0 \\
\hline $\begin{array}{c}\text { Saxton-Rawls } 2 \\
(2006)^{\mathrm{b}}\end{array}$ & 2.08 & -1.00 & -14.0 & 0.92 & 0.39 & 5.0 & 7.38 & 5.19 & 11.0 & 9.89 & -7.75 & -11.0 \\
\hline
\end{tabular}

aUsing the $K_{S}$ calculated with the equations proposed by reference [27].

bUsing the $K_{S}$ obtained from the laboratory determinations.

In the four soils evaluated, all the Green \& Ampt models considered had a lower accuracy in the soil of sample 10 that has a high content of organic matter and Silty loam texture. Because of the 
physical characteristics of this soil, it could be said that the flow is applied in piston flow and the other hypotheses suggested by Green and Ampt, so the decrease in the quality of performance from the models is attributed to; the use of an altered sample of the soil which could not be the most advisable to estimate the hydraulic conductivity at saturation in the laboratory for soils with high contents of organic matter, and to the use of equations and a database that also do not contemplate soils with high contents of organic matter.

The good accuracy of the Retention curve model suggests that the hypotheses suggested by Green \& Ampt are fulfilled in the soils evaluated and that the procedures followed in this model to obtain parameters $\psi_{f}, K_{S}$ and $\theta_{S}$ are adequate.

The Saxton-Rawls 2 (2006) model resulted in a similar accuracy to the Retention curve; however, once the parameter $\psi_{b}$ is estimated, the water retention curve is required to calculate the parameter $\lambda$ and with them the parameter $\psi_{f}$, in addition used the parameter $K_{S}$ obtained in the laboratory and not the one estimated with the empirical equations found by Saxton and Rawls (2006). If the Saxton-Rawls 1 (2006) model, in which the parameter $K_{S}$ was estimated in function of the texture and the content of organic matter, had been found to be more accurate, the value of the parameter $\lambda$ could be obtained through an inverse process using an infiltration test executed in the field. The inconvenience of obtaining the values for parameters $K_{S}$ and $\psi_{f}$ inversely is that there is a risk of not representing the hydrodynamic characteristics of the soils if there is not enough experience, since these parameters could satisfy only one numerical solution, so that to guarantee a good result one must have fully identified the parameter to be optimized [40].

The results from the evaluations suggest the need to obtain values from the parameters of the Green \& Ampt equation that are suitable to the characteristics of the soils in Mexico, to obtain more accurate estimations from the infiltration. According to the results found in this research, the water retention curve must be used to obtain parameter $\psi_{f}$ as was done in the Retention curve method and this curve could be generated taking into consideration the physical properties of the soils as was done in reference [41], contemplating the sand, clay, and organic matter contents, and the bulk density from the soils representative of the country to minimize the costs of the studies. Another alternative could be the study of empirical functional relations to obtain directly the parameter $\psi_{f}$ in function of the contents of sand, clay and the porosity of the soil; these equations have to be specific for soil uses to improve the representativeness of their characteristics [15, 42, 43].

\section{Conclusions}

It is a challenge to obtain the adequate values of the parameters of the Green \& Ampt equation, especially the wetting front capillary pressure head, because of the field and laboratory studies demanded and due to the analysis of information and costs implicated. The parameters of wetting front capillary pressure head and the saturated hydraulic conductivity from the Green \& Ampt equations were determined with different procedures from some agricultural soils in Mexico of six textural classes, and their representativeness was evaluated through the comparison of the estimated infiltrated depths compared to those obtained in the field with a double-ring infiltrometer. The mean values found by Rawls et al. (1983) by texture class, and recommended for soils in Mexico, turned out to be inadequate with a drastic underestimation of the infiltrated depths measured, and the most representative were those obtained from the water retention curve in the case of the wetting front capillary pressure head and with the constant head permeameter for the saturated hydraulic conductivity.

Finally, obtaining the parameters from the Green \& Ampt equation from agricultural soils in Mexico is recommended, and the adaptation of the Brooks and Corey method that was made in this study is suggested to obtain the wetting front capillary pressure head. 
Author Contributions: Jorge Víctor Prado Hernández directed the research and wrote the article. Fermín Pascual Ramírez coordinated the field phase and reviewed the text. David Cristóbal Acevedo coordinated the laboratory work. Mauricio Carrillo García and Antonio Martínez Ruíz processed the information and reviewed the text.

Conflicts of Interest: The authors declare not having conflicts of interest.

\section{References}

1. Rendón, L.; Fuentes, C.; Magaña, G. Diseño de riego por gravedad. In IX Curso Internacional de Sistemas de Riego, Memorias del curso, Departamento de Irrigación, Universidad Autónoma Chapingo, junio; Sánchez, B. R; Martínez, E. R., Eds.; Universidad Autónoma Chapingo, Chapingo, Estado de México, Méx., 2003.

2. Chow, V. T.; Maidment, D. R; Mays, L. W. Hidrología aplicada. McGraw-Hill Interamericana S.A.: Santafé de Bogotá, Colombia, 1994; pp. 110 - 129.

3. Guevara, E.; Márquez, A. Parametrización de modelos de infiltración basada en pruebas de campo de suelos agrícolas de la cuenca del río Chirgua, Venezuela. http://www.ingenieriadelagua.com/2004/JIA/Jia2009/fs/BP17rev.pdf (accessed on 28 March)

4. Aparicio, F. Fundamentos de hidrología de superficie. Limusa S.A. de C.V.: México, D. F., $1992 ;$ pp. 177-201.

5. Faci, J.; Playán, E. Riego por superficie. In VII Curso Internacional de Riego y Drenaje, San Fernando de Henares, Madrid; MAPA-IRYDA, Eds.; Centro Nacional de Tecnología de Regadíos (CENTER): San Fernando de Henares, Madrid, 1994, pp. 1-9.

http://hdl.handle.net/10261/17141 (accessed on 11 May 2016)

6. Green, W.H.; Ampt, G. A. Studies of soil physics, part I - the flow of air and water through soils. J. Ag. Sci. 1911, 4, 1-24.

http://dx.doi.org/10.1017/S0021859600001441

7. Ma, Y.; Feng, S.; Zhan, H.; Liu, X.; Su, D.; Kang, S.; Song, X. Water Infiltration in Layered Soils with Air Entrapment: Modified Green-Ampt Model and Experimental Validation. J. Hydrol. Eng. 2011, 16, 628-638. http://dx.doi.org/10.1061/(ASCE)HE.1943-5584.0000360

8. Mohammadzadeh-Habili, J.; Heidarpour, M. Application of the Green-Ampt model for infiltration into layered soils. J. Hydrol. 2015, 527, 824-832.

http://dx.doi.org/10.1016/j.jhydrol.2015.05.052

9. Schmidt, J.; Govindaraju, R. Predicting Flow in Subsurface Agricultural Drains Using the Green-Ampt Model. In proceedings of the conference World Water \& Environmental Resources Congress, Philadelphia, Pennsylvania, United States, june 23-26; Bizier, P.; De Barry, P., Eds.; American Society of Civil Engineers (ASCE): Pennsylvania, United States, 2003, 1-10. http://dx.doi.org/10.1061/40685(2003)197

10. Killen, M.; Slack, D. Green-Ampt-Model to Predict Surge Irrigation Phenomena. J. Irrig. Drain Eng. 1987, 113, 575-584.

http://dx.doi.org/10.1061/(ASCE)0733-9437(1987)113:4(575)

11. Chu, S. Green-Ampt Analysis of Wetting Patterns for Surface Emitters. J. Irrig. Drain Eng. 1994, 120, 414-421.

http://dx.doi.org/10.1061/(ASCE)0733-9437(1994)120:2(414)

12. Sepaskhah, A. R.; Chitsaz, H. Validating the Green-Ampt Analysis of Wetted Radius and Depth in Trickle Irrigation. Biosystems Engineering 2004, 89, 231-236.

http://dx.doi.org/10.1016/j.biosystemseng.2004.06.011

13. DeBoer, D.; Chu, S. Sprinkler Technologies, Soil Infiltration, and Runoff. J. Irrig. Drain Eng. 2001, 127, 234-239. http://dx.doi.org/10.1061/(ASCE)0733-9437(2001)127:4(234)

14. Van Mullem, J. A. Runoff and peak deschargues using Green-Ampt infiltration model. J. Hydraul. Eng. 1991, 117, 354-370. 
http://dx.doi.org/10.1061/(ASCE)0733-9429(1991)117:3(354)

15. Ficklin, D. L.; Zhang, M. A comparison of the curve number and Green-Ampt models in an agricultural watershed. Transactions of the ASABE 2013, 56, 61-69.

http://dx.doi.org/10.13031/2013.42590

16. Baiamonte, G.; Singh, V. Analytical Solution of Kinematic Wave Time of Concentration for Overland Flow under Green-Ampt Infiltration. J. Hydrol. Eng. 2015, 21, 04015072. http://dx.doi.org/10.1061/(ASCE)HE.1943-5584.0001266

17. Hillel, D. Environmental soil physics. Academic Press: San Diego, CA, USA, 1998.

18. Scott, D. Soil Physics: Agriculture and Environmental Applications. Wiley-Blackwell: Iowa, USA, 2000.

19. Fuentes, R. C. Capítulo I: Caracterización mínima del suelo con fines de riego. In Manual para diseño de zonas de riego pequeñas; De León, M. B.; Robles, R. B. D., Eds.; Instituto Mexicano de Tecnología del Agua: Jiutepec, Morelos, Méx., 2007, pp. 3-15.

20. Rendón, L.; Saucedo, H.; Fuentes, C. Capítulo 7: Diseño del riego por gravedad. In Riego por Gravedad; Fuentes, C.; Rendón, L., Eds.; Universidad Autónoma de Querétaro: Querétaro, México, 2012.

21. Castanedo, V.; Saucedo, H.; Fuentes, C. Comparación entre un modelo hidrodinámico completo y un modelo hidrológico en riego por melgas. Agrociencia 2013, 47, 209-223.

http://www.colpos.mx/agrocien/Bimestral/2013/abr-may/abr-may-13.html

(accessed on 03 March 2016)

22. Brooks, R.; Corey, A. Hydraulic properties of porous media. Hydrology Paper No. 3, Colorado State University: Fort Collins, Colorado, USA, 1964.

https://dspace.library.colostate.edu/bitstream/handle/10217/61288/HydrologyPapers n3.pdf?se quence=1 (accessed on 17 March 2016)

23. Brakensiek, D. L. Etimating the effective capillary pressure in the Green and Ampt infiltration equation. Water Resour. Res. 1977, 13, 680-682.

http://dx.doi.org/10.1029/WR013i003p00680

24. Ogden, F. L.; Saghafian, B. Green and Ampt infiltration with redistribution. J. Irrig. Drain. Eng. 1997, 123, 386-393.

http://dx.doi.org/10.1061/(ASCE)0733-9437(1997)123:5(386)

25. Rawls, W.; Brakensiek, D.; Miller, N. Green-Ampt Infiltration Parameters from Soil Data. J. Hydraul. Eng. (ASCE) 1983, 109, 62-70. http://dx.doi.org/10.1061/(ASCE)0733-9429(1983)109:1(62)

26. Corey, A. T.; Brooks, R. H. The Brooks-Corey Relationships. In proceedings of the international Workshop on Characterization and measurement of the hydraulic properties of unsaturated porous media, Riverside, Ca, USA, october 22-24; Van Genuchten, M. Th.; Leij, F. J., Wu, L., Eds.; Universidad de California: Riverside, Ca, USA, 2009, Part 1, 13-8.

27. Saxton, K.; Rawls, W. Soil Water Characteristic Estimates by Texture and Organic Matter for Hydrologic Solutions. Soil Sci. Soc. Am. J. 2006, 70(5), 1569-1578.

http://dx.doi.org/10.2136/sssaj2005.0117

28. Brakensiek, D. L.; Engleman, R. L.; Rawls, W. J. Variation within Texture Classes of Soil Water Parameters. Transactions of the ASAE 1981, 24, 335-339.

http://dx.doi.org/10.13031/2013.34253

29. Rawls, W. J., and Brakensiek, D. L. Estimating soil water retention from soil properties. J. Irrig. Drain. Division (ASCE) 1982, 108, 166-171.

http://cedb.asce.org/CEDBsearch/record.jsp?dockey=0034246 (accessed on 24 June 2016)

30. Saxton, K.; Rawls, W.; Romberger, J.; Papendick, R. Estimating Generalized Soil-water Characteristics from Texture. Soil Sci. Soc. Am. J. 1986, 50, 1031-1036. doi:10.2136/sssaj1986.03615995005000040054x

http://handle.nal.usda.gov/10113/35

31. Dirksen, C. Direct hydraulic conductivity measurements for evaluating approximate and indirect determinations. In proceedings of the international Workshop on Characterization 
and measurement of the hydraulic properties of unsaturated porous media, Riverside, Ca, USA, october 22-24; Van Genuchten, M. Th.; Leij, F. J., Wu, L., Eds.; Universidad de California: Riverside, Ca, USA, 2009, Part 1, 271-278.

32. Faybishenko, B. Comparison of laboratory and field methods for determining the Quasisaturated hydraulic conductivity of soils. Proceedings of the international Workshop on Characterization and measurement of the hydraulic properties of unsaturated porous media, Riverside, Ca, USA, october 22-24; Van Genuchten, M. Th.; Leij, F. J., Wu, L., Eds.; Universidad de California: Riverside, Ca, USA, 2009, Part 1, 279-292.

33. SEMARNAT (Secretaría de Medio Ambiente y Recursos Naturales). Norma Oficial Mexicana que NOM-021-SEMARNAT-2000 que establece las especificaciones de fertilidad, salinidad y clasificación de suelos, estudio, muestreo y análisis. Diario Oficial de la Federación. México. http://www.semarnat.gob.mx/leyes-y-normas/nom-suelos (accessed on 22 July 2016)

34. Gutiérrez, H.; De la Vara, R. Control estadístico de calidad y seis sigma. 2a. ed.; McGraw-Hill Interamericana, S.A de C.V: México, D. F., 2009.

35. Flint, L. E.; Hudson, D. B.; Flint, A. L. Unsaturated hydraulic parameters determined from direct and indirect methods. In proceedings of the international Workshop on Characterization and measurement of the hydraulic properties of unsaturated porous media, Riverside, Ca, USA, october 22-24; Van Genuchten, M. Th.; Leij, F. J., Wu, L., Eds.; Universidad de California: Riverside, Ca, USA, 2009, Part 1, 293-302.

36. Stolf, R.; De Mendoça, A.; Oliveira, O.; Bacchi, S.; Reichardt, K. Method to estimate soil macroporosity and microporosity base don sand content and bulk density. R. Bras. Ci. Solo 2011, 35, 447-459. http://dx.doi.org/10.1590/S0100-06832011000200014

37. INEGI (Instituto Nacional de Estadística y Geografía). Mapa digital de suelos de la República Mexicana V6.1, escala 1:250 000, período 2002-2007.

http://gaia.inegi.org.mx/mdm6/?v=bGF0OjE5LjcwNjAwLGxvbjotMTAxLjE4NDM1LHo6NCxs OmM0MTY (accessed on 15 April 2016)

38. Brutsaert, W. Some Methods of Calculating Unsaturated Permeability. Transactions of the American Society of Agricultural Engineers 1967, 10, 400-404.

http://dx.doi.org/10.13031/2013.39683

39. Teh, C. B. S.; Iba, J. Accuracy of the Saxton-Rawls Method for Estimating the Soil Water Characteristics for Mineral Soils of Malaysia. Pertanika J. Trop. Agric. Sci. 2010, 33, 297 - 302. http://www.pertanika.upm.edu.my/Pertanika\%20PAPERS... (accessed on 28 October 2016)

40. Hopmans, J. W.; Šimůnek, J. Review of inverse estimation of soil hydraulic properties. In proceedings of the international Workshop on Characterization and measurement of the hydraulic properties of unsaturated porous media, Riverside, Ca, USA, october 22-24; Van Genuchten, M. Th.; Leij, F. J., Wu, L., Eds.; Universidad de California: Riverside, Ca, USA, 2009, Part 1, 643-659.

41. Rajkai, K.; Kabos, S.; Van Genuchten, M. Th. Estimating the water retention curve from soil properties: comparison of linear, nonlinear and concomitant variable methods. Soil $\mathcal{E}$ Tillage Research 2004, 79, 145-152. http://dx.doi.org/10.1016/j.still.2004.07.003

42. Rawls, W. J.; Brakensiek, D. L.; Savabi, M. R. Infiltration parameters for rangeland soils. J. of Range Management 1989, 42, 140-142.

https://journals.uair.arizona.edu/index.php/jrm/article/view/8353 (accessed on 13 October 2016)

43. King, K. W.; Arnold, J. G.; Bingner, R. L. Comparison of Green-Ampt and Curve Number methods on Goodwin creek watershed using SWAT. Transactions of the ASABE 1999, 42, 919925. http://dx.doi.org/10.13031/2013.13272

(C) 2016 by the authors; licensee Preprints, Basel, Switzerland. This article is an open access article distributed under the terms and conditions of the Creative Commons by Attribution (CC-BY) license (http://creativecommons.org/licenses/by/4.0/). 